Jurnal Teknologi Informasi dan Ilmu Komputer (JTIIK)

Vol. 3, No. 2, Juni 2016, hlm. 115-125

\title{
RANCANG BANGUN APLIKASI PENGUKUR KESEHATAN FUNGSI PARU MANUSIA MEMANFAATKAN MICROPHONE PADA SMARTPHONE
}

\author{
Wahyu Teja Kusuma ${ }^{1}$, Eko Sakti Pramukantoro ${ }^{2}$, Susanthy Djajalaksana ${ }^{3}$ \\ 1,2,3 Program Studi Informatika Fakultas Ilmu Komputer \\ Email: tejawahyu@gmail.com
}

(Naskah masuk: 20 Mei 2016, diterima untuk diterbitkan: 20 Juni 2016)

\begin{abstract}
Abstrak
Penyakit Paru Obstruktif Kronik (PPOK) dapat ditandai dengan hambatan aliran udara di saluran nafas yang tidak sepenuhnya reversibel. Hasil penelitian pada bulan Januari-Desember 2010 menyebutkan bahwa PPOK menduduki urutan ke-3 dari penyakit paru terbanyak yang ada di RS Paru Batu Malang. Sedangkan di RSU Dr. Saiful Anwar Malang menduduki urutan ke-5. The Burden of Disease Study dibawah naungan WHO menyatakan bahwa pada tahun 2030 PPOK akan menempati peringkat ke-3 penyebab kematian di dunia. Sebagai solusi terhadap masalah tersebut yaitu dengan membangun sebuah aplikasi pengukur kesehatan fungsi paru manusia memanfaatkan microphone pada smartphone”. Guna mengetahui gangguan ventilasi paru, monitoring pengobatan, dan menilai perkembangan fungsi paru. Media smartphone dipilih karena memiliki teknologi Microphone API yang digunakan untuk menangkap input berupa rekaman suara hembusan napas pengguna. Dan mayoritas masyarakat telah melilikinya. Dari hasil pengujian validasi dapat disimpulkan bahwa aplikasi pengukur kesehatan paru manusia pada media smartphone berhasil diimplementasikan dengan memanfaatkan teknologi microphone. Dari hasil pengujian akurasi yang dilaksanakan di Rumah Sakit Saiful Anwar Kota Malang dapat disimpulkan bahwa ditemukan selisih akurasi Prediksi Nilai Acuan Normal sebesar FEV1 = 0,11 liter; FVC $=0,152432432$ liter; FEV1/FVC $=4,742432432 \%$. Dan selisih akurasi Hasil Pengukuran sebesar FEV1 = -1,545945946 liter; FVC = -2,892432432 liter; FEV1/FVC = 11,52243243\%.
\end{abstract}

Kata Kunci: Penyakit, Paru, Obstruktif, Kronik, Microphone, Smartphone.

\begin{abstract}
Chronic Obstructive Pulmonary Disease (COPD) can be characterized by air flow resistance in the airway that is not fully reversible. The results of the study in January-December 2010 states that COPD ranks 3rd from most existing lung disease Pulmonary Hospital Batu Malang. Meanwhile, in Hospital Dr Saiful Anwar5 ranks. The Burden of Disease Study under the auspices of the WHO stated that by 2030 COPD will be ranked as the third leading cause of death in the world. As a solution to these problems is to build an application measuring the health of human lung function utilizing a microphone on a smartphone". In order to determine pulmonary ventilation disorders, treatment monitoring, and assessing the development of lung function. Media Smartphone Microphone technology chosen because it has an API that is used to capture the input of the user breath sound recordings. And the majority of people have melilikinya. From the results of the validation testing can be concluded that the application of measuring the health of the human lung on a smartphone media successfully implemented by utilizing the microphone. Accuracy of test results conducted at Saiful Anwar Hospital Malang can be concluded that the prediction accuracy differences were found Normal Reference Values for FEV $1=0.11$ liters; $F V C=0.15$ liters; FEV $1 / F V C=4.74 \%$. And the difference in the accuracy of measurement results for FEVI $=-1.54$ liter; $F V C=-2.89$ liter; FEV $1 / F V C=11.52 \%$.
\end{abstract}

Keyword: Chronic, Obstructive, Pulmonary, Disease, Microphone, Smartphone. 


\section{PENDAHULUAN}

\subsection{Latar belakang}

Penyakit Paru Obstruktif Kronik (PPOK) adalah penyakit yang ditandai dengan hambatan aliran udara di saluran nafas yang tidak sepenuhnya reversibel. Hambatan aliran udara ini bersifat progresif dan berhubungan dengan respon inflamasi paru terhadap partikel gas beracun atau berbahaya (Keputusan Menteri, 2008).

RS Paru Batu Jawa Timur adalah rumah sakit rujukan untuk penyakit paru di propinsi Jawa Timur bagian selatan. Berdasarkan penelitian yang dilakukan oleh Ika, menyebutkan bahwa pada bulan Januari-Desember 2010 PPOK menduduki urutan ke-3 dari penyakit paru terbanyak yang ada di RS Paru Batu Malang. 896 orang diantaranya adalah pasien rawat jalan dan 164 orang adalah pasien rawat inap dalam kurun waktu satu tahun. Di RSU Dr. Saiful Anwar Malang pada Januari-Desember 2010 penderita PPOK menduduki urutan ke-5 dari kelompok penyakit paru. 956 orang diantaranya adalah pasien lama dan 62 orang pasien baru, sedangkan yang menjalani rawat inap sebanyak 241 orang (RINI, 2011).

Disertai dengan meningkatnya jumlah perokok dan polusi udara maka diduga jumlah penderita Penyakit Paru Obstruktif Kronik (PPOK) akan terus meningkat. The Burden Of Disease Study dibawah naungan WHO menyatakan bahwa pada tahun 2020 PPOK akan menempati peringkat ke-3 penyebab kematian di dunia (KARA, 2005).

Oleh karena itu dibutuhkan alat untuk mengukur kapasitas udara di paru-paru yang selama ini disebut spirometer (Modul Pelatihan, 2005). Guna mengetahui gangguan ventilasi paru, monitoring pengobatan, dan menilai perkembangan fungsi paru. Dilihat dari fungsinya, spirometer adalah alat penting yang harus dimiliki rumah sakit. Tetapi tinggi atau mahalnya harga spirometer menyebabkan tidak semua rumah sakit dapat memilikinya. Sehingga penanganan terhadap penderita gangguan ventilasi paru sering terlambat dan berakibat fatal.

Berdasarkan permasalahan yang telah dikemukakan, penulis mengusulkan skripsi dengan judul "Rancang Bangun Aplikasi Pengukur Volume Dan Kapasitas Fungsi Paru Manusia Memanfaatkan Microphone Pada Smartphone". Media smartphone dipilih karena memiliki teknologi Microphone API yang digunakan untuk menangkap input berupa rekaman suara hembusan napas pengguna. Dan sekarang ini smartphone telah menjadi kebutuhan primer masyarakat. Yang artinya masyarakat dengan tingkat ekonomi menengah ke bawah dapat memilikinya.

Hasil penelitian ini berupa aplikasi yang murah dan dapat didistribusikan sampai ke pelosok daerah dengan cepat. Praktisnya pengguna dapat langsung mengecek kesehatan fungsi parunya sendiri kapanpun diinginkan. Sehingga dapat menjadi alternatif solusi untuk mengurangi angka kematian akibat gangguan paru.

\subsection{Rumusan Masalah}

Berdasarkan uraian latar belakang di atas, maka dapat dirumuskan permasalahan sebagai berikut:

1. Bagaimana cara menangkap input pernapasan menggunakan smartphone.

2. Bagaimana keakuratan hasil pengukuran aplikasi yang diusulkan bila dibandingkan dengan alat Spirometer aslinya.

\subsection{Batasan Masalah}

Batasan masalah dalam penelitian ini adalah sebagai berikut:

1. Rancang bangun aplikasi dengan memanfaatkan microphone pada smartphone.

2. Rancang bangun aplikasi berdasarkan fitur pada Spirometer, yaitu Tidal Volume (TV), Total Lung Capacity (TLC), Forced Expiratory Volume in 1 Second (FEV1), Forced Vital Capasity (FVC), FEV1/FVC, dan Kesimpulan Kesehatan Paru.

\subsection{Tujuan} berikut:

Tujuan dari penelitian ini adalah sebagai

1. Membangun aplikasi pengukur kesehatan fungsi paru yang murah dan praktis.

2. Membangun aplikasi yang dapat diandalkan untuk deteksi dini gangguan kesehatan paru.

\subsection{Manfaat}

Penelitian ini diharapkan dapat memberikan manfaat umum antara lain:

1. Mencegah resiko fatal akibat keterlambatan penanganan suatu gangguan penyakit paru (deteksi dini).

2. Mempermudah masyarakat untuk mengukur sendiri volume dan kapasitas fungsi paruparunya.

Sedangkan manfaat dibidang medis adalah:

1. Diagnostik

2. Mengevaluasi hasil pemeriksaan yang abnormal

3. Mengukur efek penyakit terhadap fungsi paru

4. Menyaring individu dengan resiko penyakit paru

5. Menilai resiko prabedah

6. Menilai prognosis

7. Menilai status kesehatan sebelum masuk program dengan aktivitas fisik berat

8. Memantau

9. Menilai hasil pengobatan 
10. Menjelaskan perjalanan penyakit yang mempengaruhi fungsi paru

11. Memonitor individu yang pekerjaanya berhubungan dengan zat berbahaya

12. Evaluasi gangguan / ketidak mampuan

13. Menilai pasien sebagai bagian program rehabilitasi

14. Menilai resiko sebagai bagian evaluasi asuransi

15. Menilai individu untuk alasan legal

16. Kesehatan masyarakat

17. Survei epidemiologi

18. Penelitian klinis

\section{TINJAUAN PUSTAKA}

\subsection{Volume dan Kapasitas Paru}

Volume paru dan kapasitas fungsi paru merupakan gambaran fungsi ventilasi sistem pernapasan. Dengan mengetahui besarnya volume dan kapasitas fungsi paru dapat diketahui besarnya kapasitas ventilasi maupun ada tidaknya gangguan fungsi paru (MENGKIDI, 2006).

Beberapa parameter yang menggambarkan volume paru adalah:

1. Volume Tidal (Tidal Volume $=\mathrm{TV}$ ), adalah volume udara paru yang masuk dan keluar paru pada pernapasan biasa. Besarnya TV pada orang dewasa sekitar $500 \mathrm{ml}$.

2. Volume Cadangan Inspirasi (Inspiratory Reserve Volume $=$ IRV), volume udara yang masih dapat dihirup kedalam paru sesudah inspirasi biasa, besarnya IRV pada orang dewasa adalah sekitar $3100 \mathrm{ml}$.

3. Volume Cadangan Ekspirasi (Expiratory Reserve Volume $=\mathrm{ERV}$ ), adalah volume udara yang masih dapat dikeluarkan dari paru sesudah ekspirasi biasa, besarnya ERV pada orang dewasa sekitar 1000-1200 ml.

4. Volume Residu (Residual Volume = RV), udara yang masih tersisa didalam paru sesudah ekspirasi maksimal sekitar $1100 \mathrm{ml}$.

TV, IRV, ERV dapat langsung diukur dengan spirometer, sedangkan

$$
\mathrm{RV}=\mathrm{TLC}-\mathrm{VC}
$$

Kapasitas paru merupakan jumlah oksigen yang dapat dimasukkan kedalam tubuh atau paruparu seseorang secara maksimal (MENGKIDI, 2006). adalah:

Yang termasuk pemeriksaan kapasitas paru

1. Kapasitas Inspirasi (Inspiratory Capacity = IC), adalah volume udara yang mausk paru setelah inspirasi maksimal atau sama dengan volume cadangan inspirasi ditambah volume tidal.

$$
\mathrm{IC}=\mathrm{IRV}+\mathrm{TV}
$$

2. Kapasitas Vital (Vital Capacity = VC), volume udara yang dapat dikeluarkan melalui ekspirasi maksimal setelah sebelumnya melakukan inspirasi maksimal (sekitar $4000 \mathrm{ml}$ ). Kapasitas vital besarnya sama dengan volume inspirasi cadangan ditambah volume tidal.

$$
\mathrm{VC}=\mathrm{IRV}+\mathrm{ERV}+\mathrm{TV}
$$

3. Kapasitas Paru Total (Total Lung Capacity = TLC), adalah kapasitas vital ditambah volume sisa.

$$
\mathrm{TLC}=\mathrm{VC}+\mathrm{RV} \text { atau } \mathrm{TLC}=\mathrm{IC}+\mathrm{ERV}+\mathrm{RV}(4)
$$

4. Kapasitas Residu Fungsional (Functional Residual Capacity = FRC), adalah volume ekspirasi cadangan ditambah volume sisa.

$$
\mathrm{FRC}=\mathrm{ERV}+\mathrm{RV}
$$

(MENGKIDI, 2006).

\subsection{Spirometer}

Spirometer dapat dengan akurat digunakan untuk mendiagnosis PPOK dan menilai derajat obstruksi saluran napas. Spirometri menjadi standard untuk mendiagnosa PPOK (FIRDAHANA, 2010).

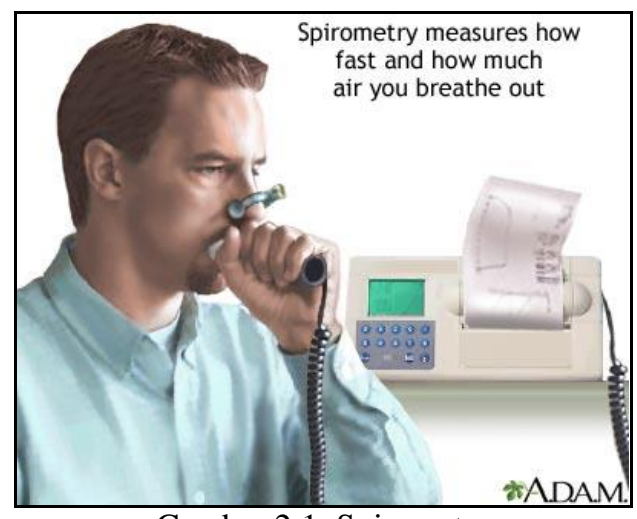

Gambar 2.1. Spirometer

Sumber: Patient Education, 2014.

Parameter pengukuran kapasitas paru yaitu:

1. Vital Capasity (VC)

Vital Capasity (VC) adalah volume udara maksimal yang dapat dihembuskan setelah inspirasi maksimal.

2. Forced Expiratory Volume in 1 Second (FEV1) Forced Expiratory Volume in 1 Second (FEV1) yaitu besarnya volume udara yang dikeluarkan dalam satu detik pertama.

3. Peak Expiratory Flow Rate (PEFR)

1. Peak Expiratory Flow Rate (PEFR) adalah aliran udara maksimal yang dihasilkan oleh sejumlah volume tertentu.

(FALASCHETTI, 2004). 


\subsection{Gangguan Fungsi Paru}

Gangguan fungsi paru digolongkan menjadi 2 bagian, yaitu:

1. Restriktif (sindrom pembatasan)

Restriktif (sindrom pembatasan) adalah gangguan pengembangan paru. Dikatakan restriktif adalah jika Kapasitas Vital Paksa $(\mathrm{FVC})<80 \%$ nilai prediksi.

2. Obstruktif (sindrom penyumbatan)

Obstruktif adalah setiap keadaan hambatan aliran udara karena adanya sumbatan atau penyempitan saluran napas. Biasanya ditandai dengan terjadi penurunan FEV1 yang lebih besar dibandingkan dengan FVC sehingga rasio FEV1/FVC kurang dari $80 \%$.

(MENGKIDI, 2006), (RAHMA, 2008).

\subsection{Interpretasi Pengukuran Paru}

Interpretasi pengukuran fungsi paru, yaitu:

1. Normal bila

$$
\text { FEV1/FVC } \geq 75 \% \text { dan FVC } \geq 80 \% .
$$

2. Gangguan restriktif bila

$$
\text { FEV } 1 / F V C \geq 75 \% \text { dan } \mathrm{FVC}<80 \%
$$

3. Gangguan obstruktif bila

(RAHMA, 2008).

$$
\mathrm{FEV} 1 / \mathrm{FVC}<75 \%, \mathrm{FVC} \geq 80 \% \text { dan }
$$$$
\text { FEV } 1<95 \% \text { pred. }
$$

Tabel 2.1. Interpretasi Hasil Pengukuran Fungsi Paru

\begin{tabular}{|l|l|l|}
\hline $\begin{array}{l}\text { Restriktif } \\
\text { FVC/Nilai } \\
\text { Prediksi (\%) }\end{array}$ & Penggolongan & $\begin{array}{l}\text { Obstruktif } \\
\text { FEV1/FVC } \\
\text { (\%) }\end{array}$ \\
\hline$\geq 80$ & NORMAL & $\geq 75$ \\
\hline $60-79$ & RINGAN & $60-74$ \\
\hline $30-59$ & SEDANG & $30-59$ \\
\hline$<30$ & BERAT & $<30$ \\
\hline
\end{tabular}

\subsection{Microphone API}

Sumber : (Modul Pelatihan, 2005).

Smartphone senantiasa berkembang sesuai dengan gaya hidup mobile manusia. Ditandai dengan semakin canggihnya perangkat input dan output. Microphone adalah salah satu perangkat input yang mengubah gelombang suara menjadi sinyal listrik. Untuk menangkap input suara, Windows Phone 8 menyediakan akses ke microphone melalui kelas Microphone pada Procedure.xaml.cs.

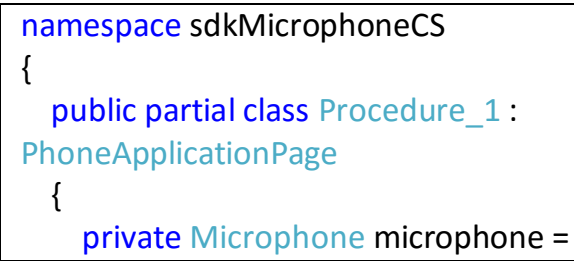

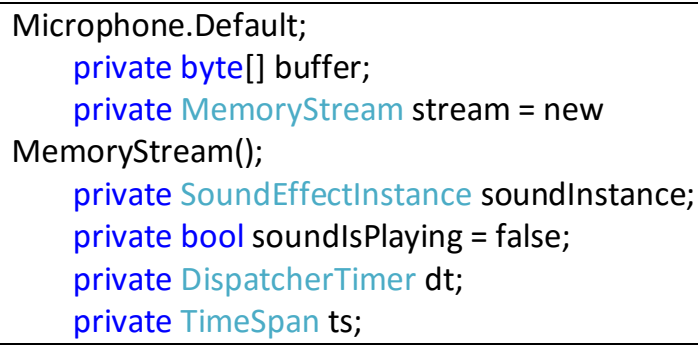

Kelas ini menyediakan akses ke semua microphone yang tersedia pada sistem dan mengekspos properti statis - Default - yang mengembalikan instance microphone. Dalam keadaan "Record", microphone mulai buffering data dan pada beberapa titik BufferReady digunakan untuk mengosongkan buffer. Hal ini berlangsung sampai pada keadaan "Stop".

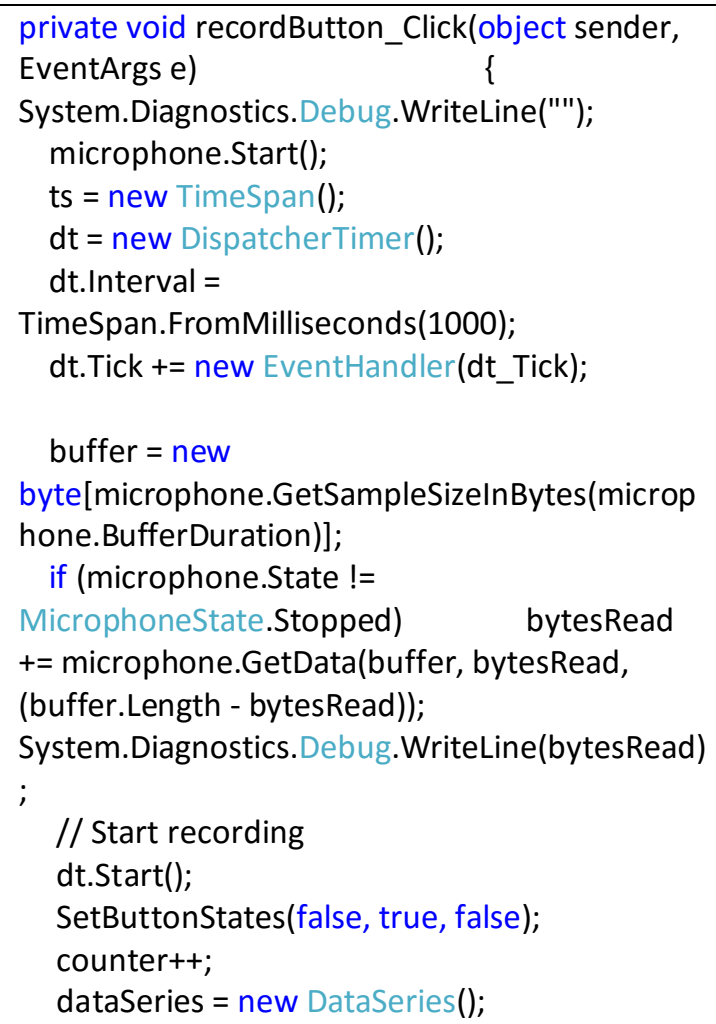

Sedangkan untuk menangkap setiap amplitudo pada rekaman pernapasan menggunakan kode berikut

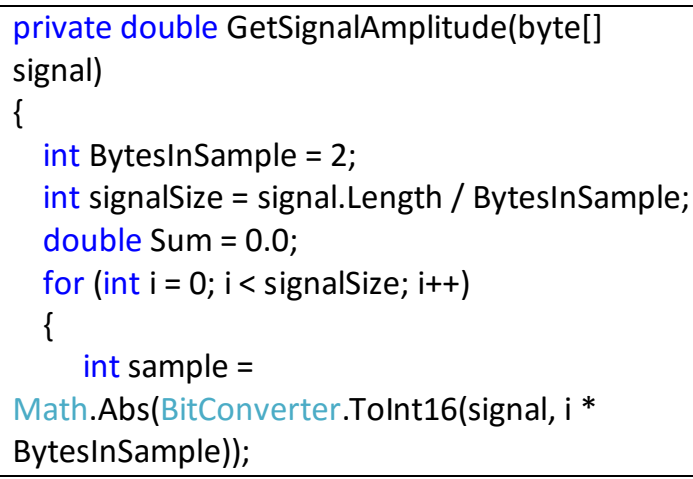




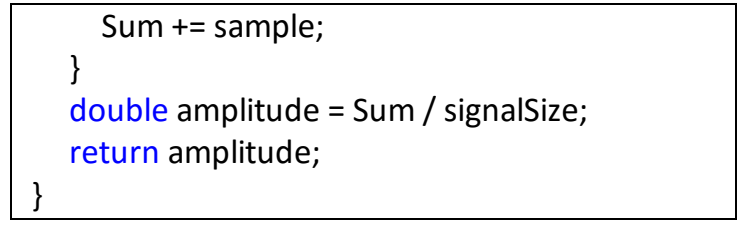

(Microphone Class, 2014).

\section{METODOLOGI PENELITIAN DAN PERANCANGAN}

Penelitian dilakukan dengan melakukan tahapan-tahapan seperti pada bagan di bawah ini:

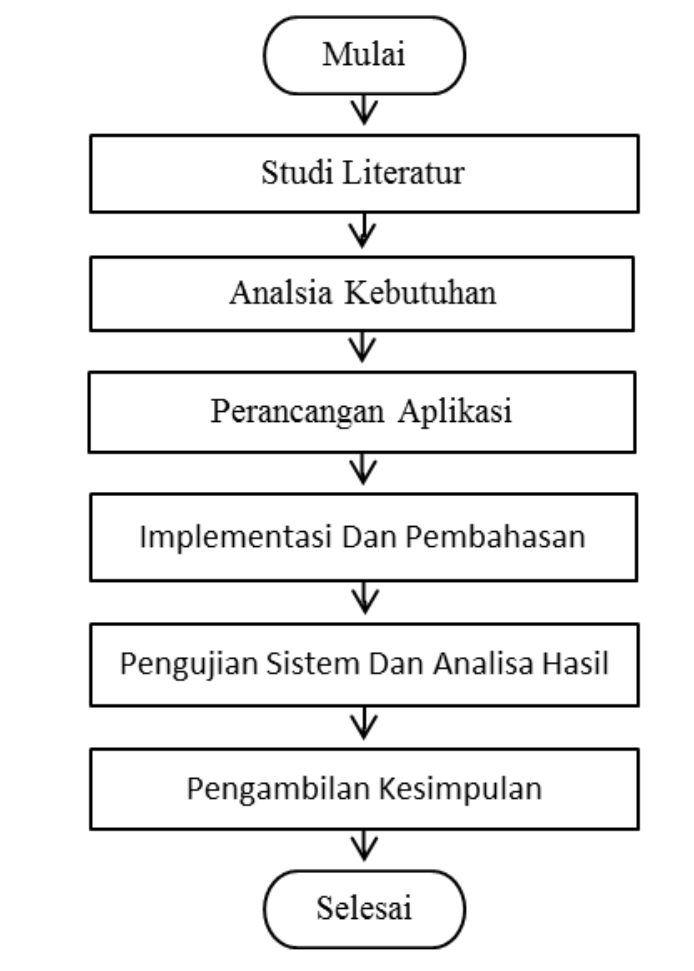

Gambar 3.1 Diagram Alir Metodologi Penelitian

Gambar 3.2 menunjukan Use Case Diagram dari sistem aplikasi pengukur kesehatan fungsi paru manusia memanfaatkan microphone pada

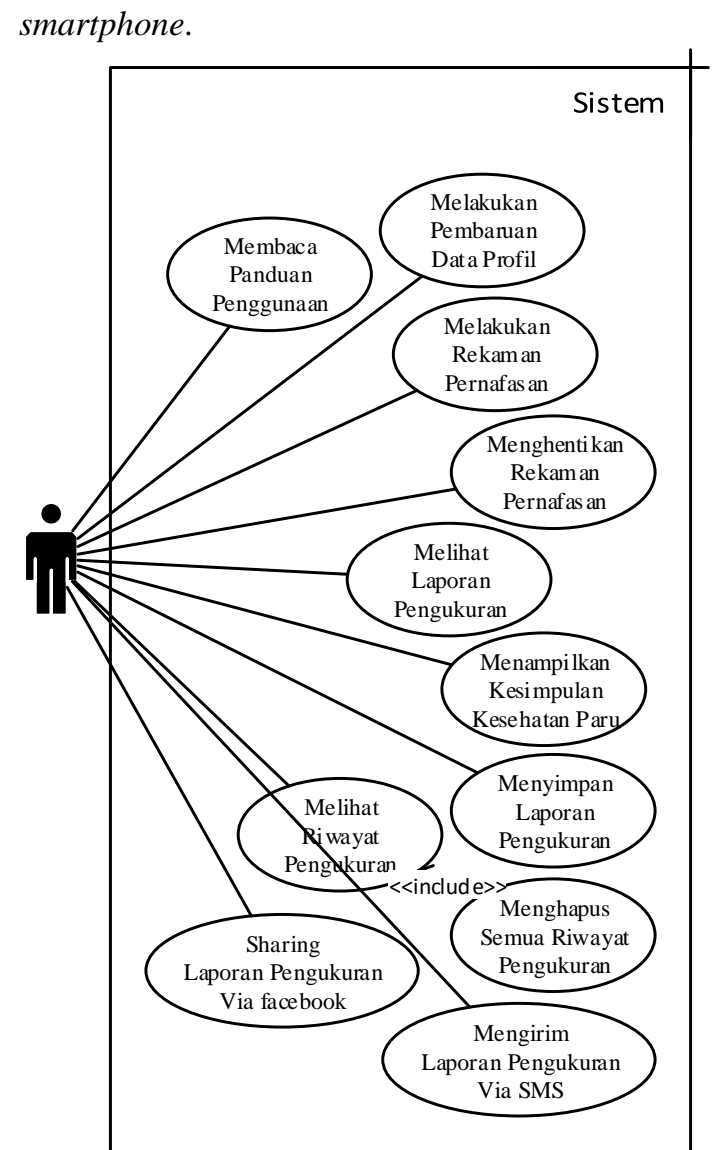

Gambar 3.2 Diagram Use Case

\section{IMPLEMENTASI DAN PEMBAHASAN}

\subsection{Lingkungan Implementasi}

Perangkat keras yang digunakan dalam pengembangan aplikasi sebagai berikut:

1. Resolusi layar 4"

2. Touch screen technology

3. Dual-core $1 \mathrm{GHz}$ Processor.

Perangkat lunak yang digunakan dalam pengembangan aplikasi sebagai berikut:

1. Windows Phone 8.

2. Visual Studio 2013

3. Xna Framework

SQLite Resolusi layar 4"

\subsection{Implementasi Microphone API}

Penerapan microphone API dibutuhkan untuk menangkap input rekaman pernapasan pengguna.

using Microsoft.Xna.Framework;
using Microsoft.Xna.Framework.Audio;

Microsoft.Xna.Framework.Audio; berisi method API yang dapat digunakan untuk memanipulasi konten file audio. 


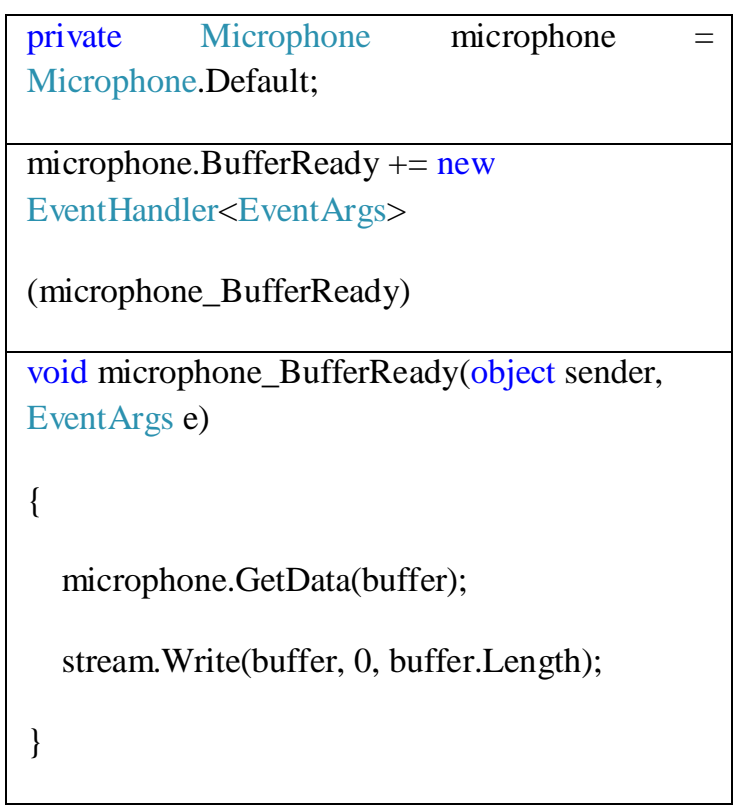

Mikrofon buffer dicatat di memori stream sampai pemutaran yang diinginkan.

private void RecordButton_Click(object sender, EventArgs e)

\{

System.Diagnostics.Debug.WriteLine("MULAI MEREKAM MICROPHONE");

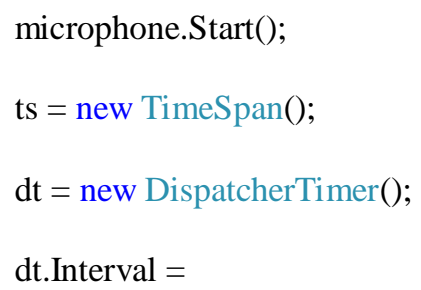

TimeSpan.FromMilliseconds(1000);

dt.Tick += new EventHandler(dt_Tick);

$$
\text { buffer }=\text { new }
$$

byte[microphone.GetSampleSizeInBytes(microp hone.BufferDuration)];

$$
\text { if(microphone.State != }
$$

MicrophoneState.Stopped)

bytesRead $+=$ microphone.GetData(buffer, bytesRead, (buffer.Length - bytesRead));

dt.Start();

SetButtonStates(false, true, false);

counter++;

dataSeries $=$ new DataSeries( $)$;

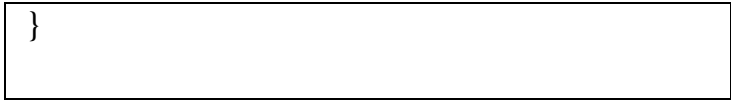

\subsection{Implementasi Pengambilan Amplitudo}

Method digunakan untuk mendapatkan amplitudo dari sinyal keseluruhan.

private double GetSignalAmplitude(byte[] signal)

\{

int BytesInSample = 2;

int signalSize $=$ signal. Length $/$

BytesInSample;

double Sum = 0.0;

for (int $\mathrm{i}=0 ; \mathrm{i}<$ signalSize; $\mathrm{i}++$ )

\{

int sample $=$

Math.Abs(BitConverter.ToInt16(signal, i *

BytesInSample));

Sum $+=$ sample;

\}

double amplitude $=$ Sum $/$ signalSize;

return amplitude;

\}

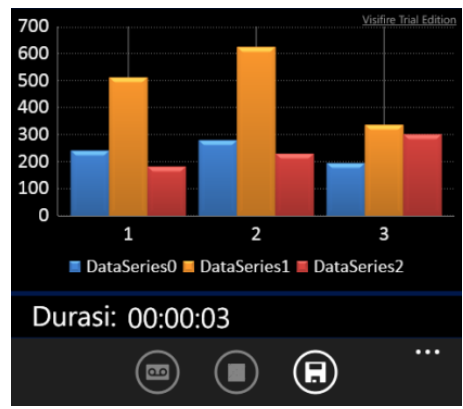

\subsection{Implementasi Perhitungan Prediksi Nilai Acuan Normal}

Code dibawah ini berfungsi untuk perhitungan prediksi nilai acuan normal kapasitas paru pengguna. Dimana nilai-nilai dan parameter-parameter perhitungan dibedakan berdasarkan jenis kelamin.

if (HasilJK.Text.Equals("L"))

\{ 

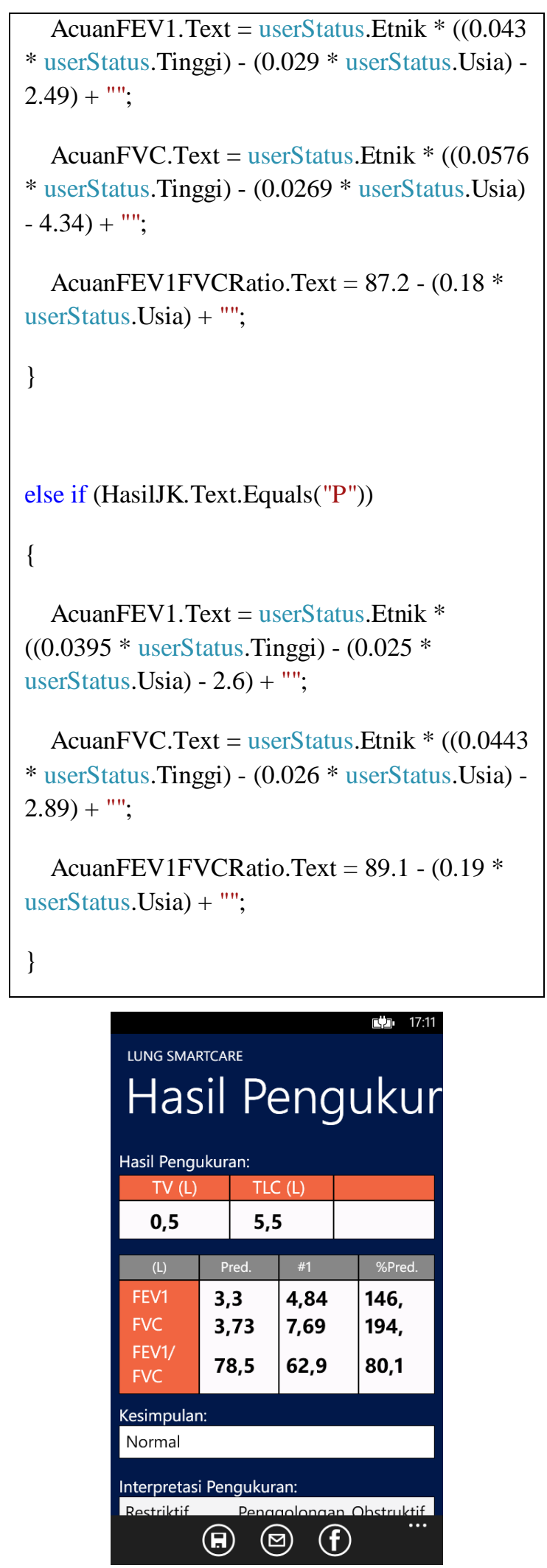

\subsection{Implementasi Perhitungan Volume dan Kapasitas Paru}

Dari rekaman pernapasan kemudian dilakukan perhitungan menggunakan code dibawah ini sehingga didapat output berupa volume tidal terbaik
(TVmax), forced vital capacity terbaik (FVCmax), dan kapasitas total paru terbaik (TLCmax).

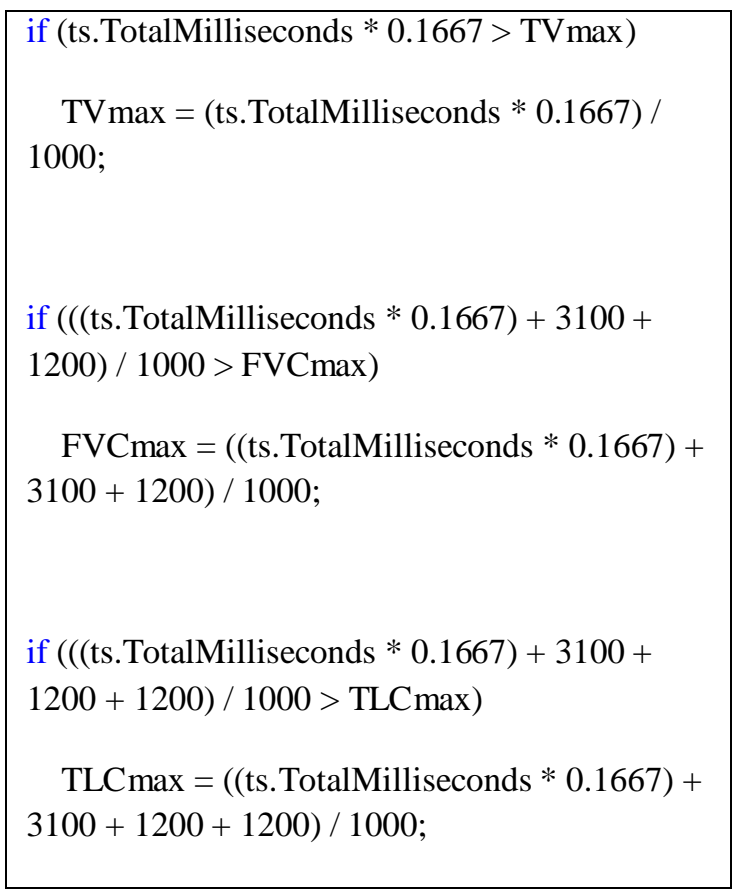

\subsection{Implementasi Parameter Pengukuran Fungsi paru}

Nilai prediksi acuan normal yang bertipe string harus dijadikan tipe double dahulu dengan cara yang ditunjukkan pada baris ke-1, 6, 11, dan 17. Kemudian setelahnya dilakukan perhitungan.

double parseAcuanFVC $=$
double.Parse(AcuanFVC.Text);
userStatus.PersenFVC = (userStatus.FVC /
parseAcuanFVC) $* 100 ;$
userStatus.PersenFVC =
Math.Round(userStatus.PersenFVC, 2);
HasilPersenFVC.Text = userStatus.PersenFVC +
"';
double parseAcuanFEV1 =
double.Parse(AcuanFEV1.Text);
userStatus.PersenFEV1 = (userStatus.FEV1 /
parseAcuanFEV1) * 100;
userStatus.PersenFEV1 =
Math.Round(userStatus.PersenFEV1, 2);
HasilPersenFEV1.Text = userStatus.PersenFEV1
+"';


double parseHasilFVC $=$

double.Parse(HasilFVC.Text);

double parseHasilFEV1 =

double.Parse(HasilFEV1.Text);

userStatus.FEV1bagiFVC = (parseHasilFEV1 / parseHasilFVC) *100;

userStatus.FEV1bagiFVC =

Math.Round(userStatus.FEV1bagiFVC, 2);

HasilFEV1bagiFVC. Text $=$

userStatus.FEV1bagiFVC + "';

double parseAcuanFEV1FVCRatio = double.Parse(AcuanFEV1FVCRatio.Text);

double parseHasilFEV1bagiFVC = double.Parse(HasilFEV1bagiFVC.Text);

userStatus.PersenFEV1bagiFVC = (parseHasilFEV1bagiFVC /

parseAcuanFEV1FVCRatio) * 100;

userStatus.PersenFEV1bagiFVC =

Math.Round(userStatus.PersenFEV1bagiFVC,

$2)$;

HasilPersenFEV1bagiFVC.Text userStatus.PersenFEV1bagiFVC + "';
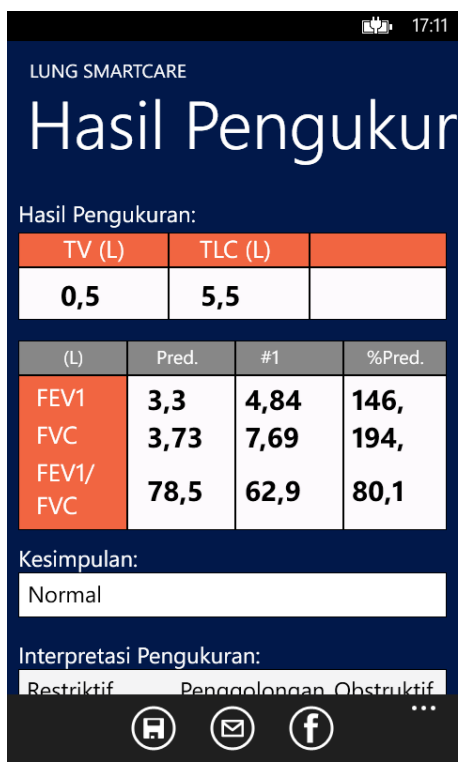

4.7 Implementasi Perhitungan Gangguan Fungsi paru
Code dibawah ini berfungsi untuk menginterpretasi kesimpulan gangguan fungsi paru. if ((userStatus.PersenFEV1bagiFVC $>=75) \& \&$ (userStatus.PersenFVC >=80))

Kesimpulan. Text = "Normal"; \}

else if ((userStatus.PersenFEV1bagiFVC >= 75) \&\& (userStatus.PersenFVC < 80))

\{

Kesimpulan.Text = "Restriktif";

\}

else if ((userStatus.PersenFEV1bagiFVC < 75) $\& \&$ (userStatus.PersenFVC $>=80) \& \&$ (userStatus.PersenFEV1 < 95))

\{

Kesimpulan. Text = "Obstruktif";

\}

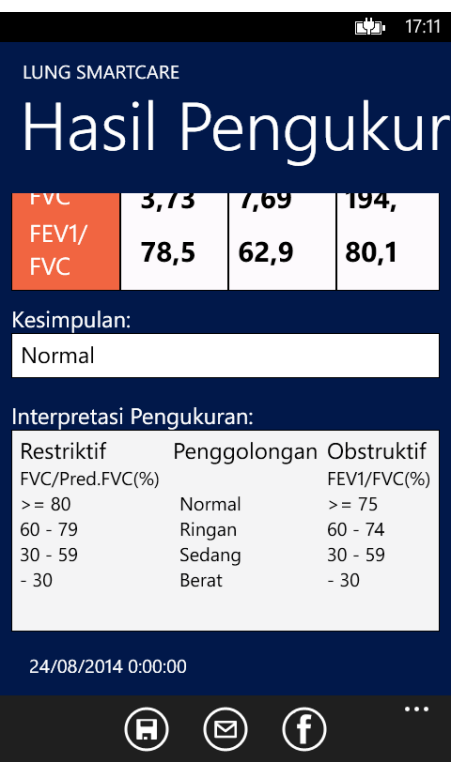

\subsection{Implementasi Local Database}

using System.IO.IsolatedStorage;

private void

SimpanHasilPengukuranButton_Click(object sender, EventArgs e) 


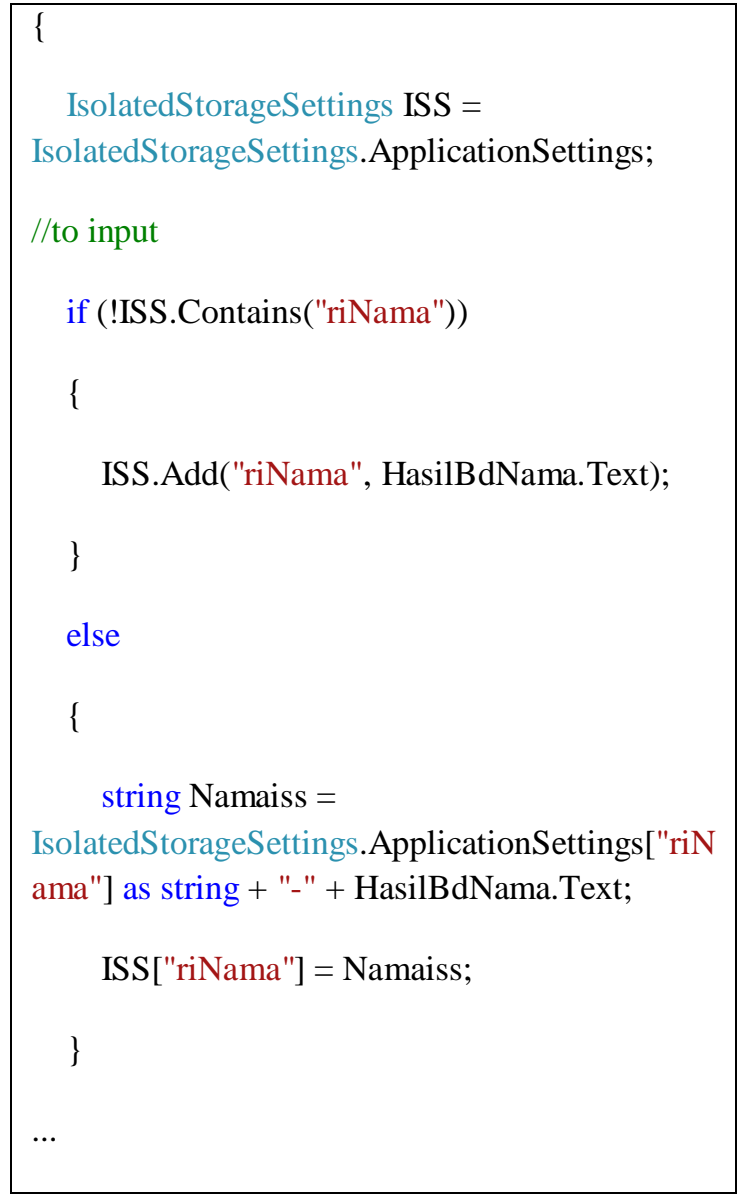

\section{PENGUJIAN DAN ANALISA HASIL}

\subsection{Pengujian Validasi}

Hasil pengujian dan validitas fitur dari uji kasus yang telah dijabarkan dapat dilihat pada Tabel 5.1 .

\begin{tabular}{|c|c|c|}
\hline No & Nama Kasus Uji & $\begin{array}{l}\text { Status } \\
\text { Validitas }\end{array}$ \\
\hline 1 & $\begin{array}{l}\text { Membaca Panduan } \\
\text { Penggunaan }\end{array}$ & Valid \\
\hline 2 & $\begin{array}{l}\text { Melakukan Pembaruan Data } \\
\text { Profil }\end{array}$ & Valid \\
\hline 3 & $\begin{array}{l}\text { Melakukan Rekaman } \\
\text { Pernapasan }\end{array}$ & Valid \\
\hline 4 & $\begin{array}{l}\text { Menghentikan Rekaman } \\
\text { Pernapasan }\end{array}$ & Valid \\
\hline 5 & Melihat Laporan Pengukuran & Valid \\
\hline 6 & $\begin{array}{l}\text { Menampilkan Kesimpulan } \\
\text { Gangguan Kesehatan Fungsi } \\
\text { Paru }\end{array}$ & Valid \\
\hline
\end{tabular}

\begin{tabular}{|l|l|l|}
\hline 7 & $\begin{array}{l}\text { Menyimpan Laporan Hasil } \\
\text { Pengukuran }\end{array}$ & Valid \\
\hline 8 & Melihat Riwayat Pengukuran & Valid \\
\hline 9 & $\begin{array}{l}\text { Menghapus Semua Riwayat } \\
\text { Pengukuran }\end{array}$ & Valid \\
\hline
\end{tabular}

\subsection{Pengujian Akurasi}

Pengujian Akurasi dilaksanakan pada tanggal 2 - 11 Juli 2014 di Ruang Unit Asma Poli Rumah Sakit Saiful Anwar Kota Malang dengan jumlah sampel populasi sebanyak 45 pasien. Pengujian Akurasi dilakukan untuk mencari selisih hasil pengukuran antara aplikasi pengukur kesehatan fungsi paru manusia memanfaatkan microphone pada smartphone dengan alat spirometer aslinya. Dari hasil pengujian tersebut ditemukan selisih akurasi Prediksi Nilai Acuan Normal sebesar FEV1 $=0,11$ liter; $\mathrm{FVC}=0,15$ liter; FEV1/FVC $=4,74 \%$. Dan selisih akurasi Hasil Pengukuran sebesar FEV1 = 1,54 liter; $\mathrm{FVC}=-2,89$ liter; FEV1/FVC $=11,52 \%$. 
Tabel. 5.1. Pengujian Akurasi

\begin{tabular}{|c|c|c|c|c|c|c|c|c|c|c|c|c|c|c|c|c|c|c|c|c|c|c|c|c|c|}
\hline \multirow{3}{*}{ No } & \multirow{3}{*}{$\mathrm{Tgl}$} & \multicolumn{6}{|c|}{ Pasien } & \multicolumn{6}{|c|}{ Aplikasi Penulis } & \multirow{2}{*}{\multicolumn{3}{|c|}{ Selisih Prediksi }} & \multirow{2}{*}{\multicolumn{6}{|c|}{$\begin{array}{ll}\text { Pengukuran } & \\
\text { Aplikasi Penulis }\end{array}$}} & \multirow{2}{*}{\multicolumn{3}{|c|}{ Selisih Pengukuran }} \\
\hline & & \multirow{2}{*}{ Nama } & \multirow{2}{*}{$\mathrm{JK}$} & \multirow{2}{*}{ Umur } & \multirow{2}{*}{ Tingg } & \multirow{2}{*}{ Berat } & \multirow{2}{*}{ Ras } & \multirow{2}{*}{\multicolumn{3}{|c|}{ Spirometri }} & \multicolumn{3}{|c|}{ Aplikasi Penulis } & & & & & & & & & enulis & & & \\
\hline & & & & & & & & FEV1 & & FEV1/FVC & FEV1 & $\mathrm{FVC}$ & FEV1/FVC & FEV1 & & FEV1/FVC & FEV1 & & FEV1/FVC & FEV1 & $\mathrm{FVC}$ & FEV1/FVC & FEV1 & & FEV1/FVC \\
\hline 1 & & Abdul Rodj; & $\mathrm{L}$ & 60 & 156 & 48 & ASIANS & 2,48 & 3,09 & 76,4 & 2,3 & 2,82 & 76,4 & $\begin{array}{ll}0,18 \\
\end{array}$ & 0,27 & 0 & 2,87 & 3,52 & 81,5 & 1,21 & 4,8 & 25,21 & 1,66 & $-1,28$ & 56,29 \\
\hline 2 & 2014 & Kholidah & $\mathrm{P}$ & 22 & 166 & 70 & ASIANS & 3,41 & 3,89 & 84,9 & 3,17 & 3,62 & 84,92 & 0,24 & 0,27 & $-0,02$ & 2,87 & 3,39 & 84,6 & 0,44 & 5,13 & 8,58 & 2,43 & $-1,74$ & 76,02 \\
\hline 3 & & \begin{tabular}{|l|l|l|} 
Ach. Fadli \\
\end{tabular} & $\mathrm{L}$ & 24 & 157 & 43 & ASIANS & 3,39 & 3,85 & 82,9 & 3,32 & 3,77 & 82,88 & 0,07 & 0,08 & 0,02 & 2,99 & 3,03 & 89,6 & 1,23 & 4,97 & 24,75 & 1,76 & $-1,94$ & 64,85 \\
\hline 4 & & Handoko & $\mathrm{L}$ & 31 & 165 & 56 & ASIANS & 3,55 & 4,22 & 84,94 & 3,45 & 4,03 & 81,62 & 0,1 & 0,19 & 3,32 & 0,76 & 1,79 & 42,46 & 7,74 & 5,47 & 141,5 & $-6,98$ & $-3,68$ & $-99,04$ \\
\hline 5 & & Soepaat & & 63 & 160 & 51 & ASIANS & 2,29 & 2,84 & 80,9 & 2,38 & 2,96 & 75,86 & $-0,09$ & $-0,12$ & 5,04 & 1,16 & 1,76 & 65,91 & 0,25 & 4,63 & 5,4 & 0,91 & $-2,87$ & 60,51 \\
\hline 6 & & Diana & $\mathrm{P}$ & 43 & 155 & 55 & ASIANS & 2,51 & 2,96 & 85,48 & 2,28 & 2,66 & 80,93 & 0,23 & 0,3 & 4,55 & 1,76 & 2,23 & 78,92 & 0 & 4,97 & 0 & 1,76 & $-2,74$ & 78,92 \\
\hline 7 & & Fadhil & $\mathrm{L}$ & 15 & 165 & 70 & ASIANS & 3,4 & 3,96 & 87,18 & 3,88 & 4,43 & 84,5 & $-0,48$ & $-0,47$ & 2,68 & 2,16 & 3,13 & 69,01 & 0 & 4,47 & 0 & 2,16 & $-1,34$ & 69,01 \\
\hline 8 & $\begin{array}{l}070147 \\
2014\end{array}$ & Tumiran & $\mathrm{L}$ & 69 & 155 & 66 & ASIANS & 1,78 & 2,24 & 80,49 & 2,02 & 2,54 & 74,7 & $-0,24$ & -0 & 5,71 & 1,4 & 2,0 & 71,78 & 0 & 4,6 & & 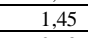 & 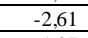 & 71,78 \\
\hline 9 & & Tukini & $\mathrm{L}$ & 64 & 160 & 64 & ASIANS & 2,26 & 2,82 & 80,76 & 2,36 & 2,93 & 75,68 & \begin{tabular}{ll|}
$-0,1$ \\
\end{tabular} & $-0,11$ & 5,08 & 2,68 & 3,43 & 78,13 & 0 & 4,8 & 0 & 2,68 & $-1,37$ & 78,13 \\
\hline 10 & & Tukina & $\mathrm{P}$ & 50 & 145 & 53 & ASIANS & 2,04 & 2,4 & 85,83 & 1,75 & 2,08 & 79,6 & 0,29 & 0,32 & 6,23 & 0,97 & 1,02 & 95,1 & 0,44 & 4,8 & 9,17 & 0,53 & $-3,78$ & 85,93 \\
\hline 11 & & Imam & $\mathrm{L}$ & 54 & 160 & 70 & ASIANS & 2,55 & 3,11 & 82,16 & 2,63 & 3,18 & 77,48 & $-0,08$ & $-0,07$ & 4,68 & 1,63 & 2,19 & 74,43 & 0 & 4,8 & 0 & 1,63 & $-2,61$ & 74,43 \\
\hline 12 & & Heri & $\mathrm{L}$ & 43 & 160 & 50 & ASIANS & 2,87 & 3,44 & 83,7 & 2,92 & 3,46 & 79,46 & $-0,05$ & $-0,02$ & 4,24 & 2,26 & 3,24 & 69,75 & 0 & 4,63 & 0 & 2,26 & $-1,39$ & 69,75 \\
\hline 13 & & Ninuk & \begin{tabular}{l|l} 
\\
\end{tabular} & 43 & 155 & 70 & ASIANS & 2,51 & 2,96 & 85,48 & 2,28 & 2,66 & 80,93 & 0,23 & 0,3 & 4,55 & 1,59 & 1,79 & 88,83 & 0,63 & 4,97 & 12,68 & 0,96 & $-3,18$ & 76,15 \\
\hline 14 & & Wempi & $\mathrm{L}$ & 65 & 160 & 82 & ASIANS & 2,23 & 2,79 & 80,62 & 2,33 & 2,91 & 75,5 & $\begin{array}{l}-0,1 \\
-1\end{array}$ & $-0,12$ & 5,12 & 1,9 & 2, & 80,33 & 0 & 4,9 & 0 & & -2 & 80,33 \\
\hline 15 & 071 & \begin{tabular}{|l|} 
Rukiyatun \\
\end{tabular} & \begin{tabular}{l|l}
$\mathrm{P}$ \\
\end{tabular} & 74 & 155 & 60 & ASIANS & 1,93 & 2,47 & 82,11 & 1,56 & 1,91 & $75, \mathrm{C}$ & 0,3 & 0, & 7,07 & 0,7 & 1, & 69,61 & 5,38 & 4 & 112,08 & -4, & -3 & $-42,47$ \\
\hline 16 & 2014 & Djumali & \begin{tabular}{l|l}
$\mathrm{L}$ \\
\end{tabular} & 72 & 160 & 62 & ASIANS & 2,02 & 2,58 & 79,64 & 2,14 & 2,73 & 74,24 & $-0,12$ & $-0,15$ & 5,4 & 0,91 & 1,53 & 59,48 & 4,24 & 4,8 & 88,33 & $-3,33$ & $-3,27$ & $-28,85$ \\
\hline 17 & & Rantansari & $\mathrm{P}$ & 25 & 155 & 48 & ASIANS & 2,85 & 3,36 & 87,45 & 2,69 & 3,09 & 84,35 & 0,16 & 0,27 & 3,1 & 1,93 & 2,18 & 88,53 & 0 & 4,97 & 0 & 1,93 & $-2,79$ & 88,53 \\
\hline 18 & & Syamsul & $\mathrm{L}$ & 55 & 160 & 65 & ASIANS & 2,52 & 3,08 & 82,02 & 2,6 & 3,16 & 77,3 & $-0,08$ & $-0,08$ & 4,72 & 1,4 & 1,97 & 71,07 & 10,76 & 5,13 & 209,75 & $-9,36$ & $-3,16$ & $-138,68$ \\
\hline 19 & & Siti & $\mathrm{P}$ & 36 & 155 & 54 & ASIANS & 2,64 & 3,08 & 86,25 & 2,44 & 2,83 & 82,26 & 0,2 & 0,2 & 3,99 & 1,19 & 1, & 82,64 & 5,7 & & 123,11 & -4 & & $-40,47$ \\
\hline 20 & & Tiami & \begin{tabular}{l|l} 
\\
$P$
\end{tabular} & 50 & 155 & 68 & ASIANS & 2,38 & 2,84 & 84,72 & 2,11 & 2,49 & 79,6 & 0,27 & 0, & 5,12 & 0,55 & 0, & 70,89 & 3,61 & 4, & 72,64 & $-3,06$ & $-4,18$ & $-1,75$ \\
\hline 21 & & Mutma & $\mathrm{P}$ & 50 & 155 & 68 & & 2,04 & 2,4 & & 2,11 & 2,49 & 79 & $-0,07$ & & & 0,9 & & 68,28 & 0 & & & & & 68,28 \\
\hline 22 & & Jumaatin & \begin{tabular}{l|l}
$P$ \\
\end{tabular} & 49 & 155 & 70 & ASIANS & 2,39 & 2,86 & 84,83 & 2,14 & 2,5 & 79,7 & 0,25 & 0, & 5,04 & 1,4 & 1, & 78,65 & 7,46 & 4,6 & 161,12 & $-6,6$ & -2 & $-82,47$ \\
\hline 23 & & Aris & \begin{tabular}{l|l} 
\\
\end{tabular} & 28 & 155 & 45 & ASIANS & 2,79 & 3,21 & 87,12 & 2,62 & 3,02 & 83,7 & 0,17 & 0, & 3,34 & 1,45 & 2,3 & 61,97 & 8,64 & 4,9 & 173,84 & $-7,19$ & $-2,63$ & $-111,87$ \\
\hline 24 & $10 / 07 /$ & Lilik & $P$ & 65 & 160 & 70 & ASIANS & 2,26 & 2,81 & 82,53 & 1,95 & 2,33 & 76,7 & 0,31 & & 5,78 & 0,75 & 1, & 57,25 & 5,54 & 4,8 & 115,42 & -4. & $-3,49$ & $-58,17$ \\
\hline 25 & 2014 & Djarwoko & \begin{tabular}{l|l}
$\mathrm{L}$ \\
\end{tabular} & 41 & \begin{tabular}{ll|}
160 \\
\end{tabular} & 50 & ASI & 2,93 & 3, & & 2,98 & 3, & 79,82 & $-0,0$ & -0, & & 1,4 & & 73,7 & & & & & & 69,32 \\
\hline 26 & & Winarni & \begin{tabular}{l|l} 
\\
\end{tabular} & 58 & \begin{tabular}{|l|}
145 \\
\end{tabular} & 53 & ASIANS & 1,89 & 2,26 & 84,96 & 1,56 & 1,8 & 78,08 & 0,33 & 0, & & 0,8 & 1,29 & 62,02 & 1,27 & 4,9 & 25,55 & $-0,47$ & & 36,47 \\
\hline 27 & & Aulia & $P$ & 21 & 155 & 45 & ASIANS & 2,93 & 3,33 & 87,88 & 2,79 & 3,19 & 85,1 & 0,14 & 0 , & 2,77 & 1,31 & 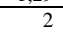 & 65,5 & 2,13 & 4,9 & 42,86 & $-0,82$ & $-2,97$ & 22,64 \\
\hline 28 & & Mentas & \begin{tabular}{l|l}
$\mathrm{L}$ \\
\end{tabular} & 44 & 160 & 59 & ASIANS & 2,8 & 3,41 & 8 & 2,9 & 3,4 & 79, & $-0,06$ & -0, & 4,28 & 0,8 & 1,5 & 52,56 & 4, & 4,9 & 94, & $-3,8$ & $-3,41$ & $-42,21$ \\
\hline 29 & & Misgiarti & \begin{tabular}{|l|l|} 
\\
\end{tabular} & 46 & 155 & 63 & ASIA & 2,45 & 2,9 & & 2,21 & 2,5 & 8 & 0,2 & 0, & 4,8 & 1, & 2,0 & 85,07 & 6 , & 5 & 127. & -5 & -3 & $-42,48$ \\
\hline 30 & & Supi & \begin{tabular}{l|l} 
\\
\end{tabular} & 56 & 155 & 52 & & 2,2 & 2,7 & & 1,97 & 2, & 78 & & 0 & 5, & 1,5 & 2, & 77,61 & $2,8+2,0$ & 5,1 & 55 & $-1,27$ & $-3,12$ & 22,44 \\
\hline 31 & & Subiran & \begin{tabular}{l|l}
$\mathrm{L}$ \\
\end{tabular} & 76 & 160 & 60 & ASI & 1, & 2,46 & & 2,03 & 2,6 & 73,5 & -0, & $-0,1$ & 5, & 2,3 & 3,3 & 70,24 & 7,51 & 4. & 156,46 & $-5,15$ & $-1,44$ & $-86,22$ \\
\hline 32 & & Srimukti & \begin{tabular}{l|l}
$P$ \\
\end{tabular} & 77 & 145 & 64 & ASIANS & 1,67 & 2,07 & 82,89 & 1,12 & 1,42 & 74,47 & 0,55 & 0, & 8,42 & 0,69 & 0, & 85,19 & 6,58 & 4,8 & 137,08 & $-5,89$ & $-3,99$ & $-51,89$ \\
\hline 33 & $11 / 07 /$ & Anang & $\mathrm{L}$ & 72 & \begin{tabular}{|l|}
160 \\
\end{tabular} & 54 & ASIANS & 2,02 & 2,58 & 79,64 & 2,14 & 2,7 & 74,24 & -0 & -0 & 5,4 & 0 & 1 , & 43,62 & 0,74 & 4,97 & 14,89 & 0,08 & $-3,09$ & 28,73 \\
\hline 34 & 2014 & Nanik & $\mathrm{P}$ & 71 & 145 & 45 & ASIANS & 1,91 & 2,25 & 83,54 & 1,26 & 1,57 & 75,61 & 0,65 & 0,68 & 7,93 & 0,99 & 1, & 69,72 & 3,64 & 4, & 75,83 & $-2,65$ & $-3,38$ & $-6,11$ \\
\hline 35 & & Sutama & $\mathrm{L}$ & 61 & 155 & 63 & ASIAI & 2,01 & 2,48 & 81 & 2,24 & 2,74 & 76,2 & $-0,23$ & -0, & 5,39 & 1,3 & 1, & 82,21 & 4 & & 103,89 & $-3,47$ & & $-21,68$ \\
\hline 36 & & Mush & \begin{tabular}{l|l|}
$\mathrm{P}$ \\
\end{tabular} & 74 & 150 & 37 & ASI & 1,86 & 2,32 & & 1, & 1 & & 0 & & & 0, & 1, & 65, & & & 12 & $-5,42$ & & $-62,74$ \\
\hline 37 & & Mudjilah & \begin{tabular}{l|l|}
$P$ \\
\end{tabular} & 58 & \begin{tabular}{|l|}
156 \\
\end{tabular} & 51 & ASIANS & 2,26 & 2,75 & 83,74 & 1,96 & \begin{tabular}{|l|}
2,34 \\
\end{tabular} & 78,08 & 0,3 & 0,41 & 5,66 & 1,62 & 1,88 & 86,17 & 1,09 & 5,13 & 21,25 & 0,53 & $-3,25$ & 64,92 \\
\hline & & & & & & & & & & Kata-1 & ih Predil & i Nilai $\mathbf{A}$ & rmal & $0,11 \mathrm{~L}$ & $0,15 \mathrm{~L}$ & $4,47 \%$ & & & & 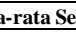 & isih Nila & kuran & $1,54 \mathrm{~L}$ & $-2,89 \mathrm{~L}$ & $11,52 \%$ \\
\hline
\end{tabular}




\section{PENUTUP}

6.1. Kesimpulan

Berdasarkan hasil perancangan, implementasi dan pengujian yang dilakukan, maka diambil kesimpulan sebagai berikut:

1. Aplikasi pengukur kesehatan paru manusia pada media smartphone berhasil diimplementasikan dengan memanfaatkan teknologi microphone.

2. Ditemukan Selisih akurasi antara aplikasi pengukur kesehatan fungsi paru manusia memanfaatkan microphone pada smartphone dengan alat Spirometer di Rumah Sakit Saiful Anwar Kota Malang (RSSA) pada Prediksi Nilai Acuan Normal sebesar FEV1 = 0,11 liter; $\mathrm{FVC}=0,15$ liter; FEV1/FVC $=4,74 \%$. Dan selisih akurasi pada Hasil Pengukuran sebesar FEV1 = -1,54 liter; $\mathrm{FVC}=-2,89$ liter; $\mathrm{FEV} 1 / \mathrm{FVC}=11,52 \%$

\subsection{Saran}

Berdasarkan permasalahan yang terjadi, maka saran yang dapat diberikan untuk pengembangan aplikasi pengukur kesehatan paru manusia memanfaatkan microphone pada smartphone antara lain:

1. Untuk meningkatkan keakuratan pengukuran sebaiknya ditambahkan fitur "Kalibrasi". Fitur Kalibrasi digunakan untuk merekam suara disekitar pengguna (noise) sebagai variabel pengurang "Hasil Pengukuran".

2. Untuk Pengujian Akurasi selanjutnya, sebaiknya jumlah sampel populasi yang digunakan sebanyak 200 pengguna/pasien.

\section{DAFTAR PUSTAKA}

RINI, I. S. 2011. Hubungan Antara Efikasi Diri Dengan Kapasitas Hidup Pasien Penyakit Paru Obstruktif Kronis Dalam Konteks Asuhan Keperawatan Di RS Paru Batu Dan RSU Dr. Saiful Anwar Malang Jawa Timur. Program Studi Magister Ilmu Keperawatan. Universitas Indonesia (hal.8-9).

Keputusan Menteri Kesehatan Republik Indonesia. Nomor 1022/MENKES/SK/XI/2008. Tentang Pedoman Pengendalian Penyakit Paru Obstruktif Kronik Menteri Kesehatan Republik Indonesia (hal.6).

KARA, M. (2005). "Preparing Nurses For The Global Pandemic Of Chronic Obstructive Pulmonary Diseace". Journal Of Nursing Scholarship.

http://www.redorbit.com/news/health/156840/p reparing nurses for the global pandemic of chronic_obstructive_pulmonary/. Diperoleh tanggal 13 Pebruari 2011 (hal. 127).

MENGKIDI, D. 2006. “Gangguan Fungsi Paru Dan Faktor-Faktor Yang Mempengaruhinya Pada Karyawan Pt. Semen Tonasa Pangkep Sulawesi Selatan". Universitas Diponegoro. Semarang (hal.24-29).

RAHMA, L. 2008. "Gambaran fungsi paru pada pekerja CV. Silkids Garmindo". FKMUI. Universitas Indonesia (hal.26-28).

Modul Pelatihan Pemeriksaan Kesehatan Kerja. Departemen Tenaga Kerja Dan Transmigrasi Badan Penelitian, Pengembangan Dan Informasi Pusat Pengembangan Keselamatan Kerja Dan Hiperkes Dipa. 2005.

FALASCHETTI E, LAIHO J, PRIMATESTA $\mathrm{P}$, PURDON S. Prediction equations for normal and low lung function from the Health Survey for England. Eur Respir J. 2004 Mar;23(3):456-63.

Patient Education - Lung Cancer Program at UCLA.

http://lungcancer.ucla.edu/adm_tests_lung_fun c.html. Diakses pada tanggal 28 Maret 2014.

SIDDHARTH, G., PETER, C., NONSO A., \& ASHUTOSH S. 2011. "mobileSpiro: Accurate mobile Spirometry for Self-Management of Asthma". Departments of ECE and CS, Rice University (hal.2-3).

Microphone Class. http://msdn.microsoft.com/enus/library/microsoft.xna.framework.audio.micr ophone.aspx. Diakses pada tanggal 28 Maret 2014.

FIRDAHANA, A. 2010. "Perbandingan Nilai Faal Paru Pada Penderita Penyakit Paru Obstruksi Kronik (PPOK) Stabil Dengan Orang Sehat". Fakultas Kedokteran. Universitas Sebelas Maret. Surakarta (hal.7). 